\title{
Magnetically Responsive Smart Nanoparticles for Cancer Treatment with a Combination of Magnetic Hyperthermia and Remote-Control Drug Release
}

\author{
Koichiro Hayashi ${ }^{1,5}{ }^{凶}$, Michihiro Nakamura ${ }^{1}$, Hirokazu Miki², Shuji Ozaki ${ }^{3}$, Masahiro Abe ${ }^{4}$, Toshio \\ Matsumoto ${ }^{4}$, Wataru Sakamoto ${ }^{5}$, Toshinobu Yogo ${ }^{5}$, Kazunori Ishimura1 \\ 1. Department of Anatomy and Cell Biology, Institute of Health Biosciences, The University of Tokushima Graduate School, 3-18-15 Ku- \\ ramoto-cho, Tokushima, 770-8503, Japan. E-mail: hayashi@tokushima-u.ac.jp \\ 2. Division of Transfusion Medicine, Tokushima University Hospital 2-50-1 Kuramoto-cho, Tokushima, 770-0042, Japan; \\ 3. Department of Internal Medicine, Tokushima Prefectural Central Hospital, 1-10-3 Kuramoto-cho, Tokushima, 770-0042, Japan; \\ 4. Department of Medicine and Bioregulatory Sciences, The University of Tokushima Graduate School of Medical Sciences, 3-18-15 Ku- \\ ramoto-cho, Tokushima, 770-8503, Japan; \\ 5. Division of Nanomaterials Science, EcoTopia Science Institute, Nagoya University, Furo-cho, Chikusa-ku, Nagoya 464-8603, Japan.
}

$\square$ Corresponding author: Koichiro Hayashi, PhD. EcoTopia Science Institute, Nagoya University, Furo-cho, Chikusa-ku, Nagoya, 464-8603, Japan Japan. E-mail: hayashi@esi.nagoya-u.ac.jp.

() Ivyspring International Publisher. This is an open-access article distributed under the terms of the Creative Commons License (http://creativecommons.org/ licenses/by-nc-nd/3.0/). Reproduction is permitted for personal, noncommercial use, provided that the article is in whole, unmodified, and properly cited.

Received: 2014.03.24; Accepted: 2014.04.17; Published: 2014.06.07

\begin{abstract}
We report the synthesis of smart nanoparticles (NPs) that generate heat in response to an alternating current magnetic field (ACMF) and that sequentially release an anticancer drug (doxorubicin, DOX). We further study the in vivo therapeutic efficacy of the combination of magnetic hyperthermia (MHT) and chemotherapy using the smart NPs for the treatment of multiple myeloma. The smart NPs are composed of a polymer with a glass-transition temperature $\left(T_{\mathrm{g}}\right)$ of $44^{\circ} \mathrm{C}$, which contains clustered $\mathrm{Fe}_{3} \mathrm{O}_{4} \mathrm{NPs}$ and DOX. The clustered $\mathrm{Fe}_{3} \mathrm{O}_{4} \mathrm{NPs}$ produce heat when the ACMF is applied and rise above $44^{\circ} \mathrm{C}$, which softens the polymer phase and leads to the release of DOX. The combination of MHT and chemotherapy using the smart NPs destroys cancer cells in the entire tumor and achieves a complete cure in one treatment without the recurrence of malignancy. Furthermore, the smart NPs have no significant toxicity.
\end{abstract}

Key words: smart nanoparticles, alternating current magnetic field, cancer cells

\section{Introduction}

Magnetic hyperthermia treatment (MHT) is a cancer therapy that relies on the heat produced by magnetic nanoparticles (NPs) under an alternating current magnetic field (ACMF), and it has the potential to realize a local, scarless, and economical treatment with fewer side effects. ${ }^{1-7}$ The magnetic NPs must heat the tumor to a temperature sufficient to destroy the tumor cells (above $42.5^{\circ} \mathrm{C}$ ) with exposure to harmless ACMF. The ACMF is considered harmless if the product of the amplitude $(H)$ and frequency $(f)$ of the field is less than $5 \times 10^{9} \mathrm{~A} \mathrm{~m}^{-1} \mathrm{~s}^{-1}$. For clinical applications of MHT, magnetic NPs must be developed with high ACMF-to-heat conversion efficiency, which is governed by their specific absorption rate (SAR).

Controlling the composition of the magnetic NPs is an effective method for increasing the SAR. However, considering the potential toxicity to the body, the number of usable elements is severely limited. ${ }^{9}$ From this perspective, magnetite $\left(\mathrm{Fe}_{3} \mathrm{O}_{4}\right)$ is the most promising material because of its low toxicity and relatively high saturation magnetization $\left(M_{\mathrm{s}}\right)^{4,9}$ Fur- 
thermore, $\mathrm{Fe}_{3} \mathrm{O}_{4}$ is already used as a contrast agent for magnetic resonance imaging (MRI) in clinical practice. ${ }^{1}$ However, individual $\mathrm{Fe}_{3} \mathrm{O}_{4}$ NPs must be concentrated at an unrealistically high level $(\sim 5 \mathrm{mg} / \mathrm{mL})$ to heat the tumor cells to the extinction temperature by the application of ACMF. ${ }^{8}$

Recently, it has been shown that the clustering of magnetic NPs induces a significant increase in the magnetic moment, and consequently, the clustered magnetic NPs have a much higher $M_{\mathrm{s}}$ and SAR than individual magnetic NPs. ${ }^{10-12}$ Therefore, clusters of magnetic NPs provide an effective method for increasing SAR without introducing harmful elements.

Few studies have reported the in vivo therapeutic efficacy of MHT. ${ }^{12-16}$ According to these studies, MHT can inhibit the growth of tumor, but it does not provide a complete cure. ${ }^{12-15}$ This finding indicates that MHT cannot completely kill the cancer cells and that the residual cancer cells regrow.

Chemotherapy is a typical cancer therapeutic. However, this treatment cannot completely kill cancer cells, and serious side effects may develop even if the anticancer drugs are injected directly into the tumor because the anticancer drugs may escape into the healthy tissue surrounding tumor. ${ }^{17}$

Combining MHT and chemotherapy may overcome the problems in the individual treatments while producing the following synergistic effects: (1) MHT shrinks cancer cells and increases the space between the cells, which would allow anticancer drugs to spread throughout the tumor and destroy the cancer cells in the entire tumor; (2) the utilization of heat generated by the magnetic NPs under ACMF as a trigger for the drug release enables the gradual release of anticancer drugs from the NPs, which prevents the anticancer drugs from leaving the tumor and reduces side effects; and (3) MHT can potentiate the effect of the anticancer drug, which enhances the destruction of cancer cells.

For drug release using heat as a trigger, the drug carriers should ideally retain their load at body temperature $\left(\sim 37^{\circ} \mathrm{C}\right)$ and release the drug within a locally heated tumor at the therapeutic temperature for hyperthermia $\left(42.5-45^{\circ} \mathrm{C}\right) .{ }^{18}$ Current thermoresponsive drug carriers include liposome ${ }^{19,20}$ or polymer NPs that exhibit a lower critical solution temperature. ${ }^{21-24}$ To release the drugs from these drug carriers in vivo, heat is generally applied using temperature-controlled water sacks or miniature annular-phased array microwave applicators. ${ }^{18}$ Unfortunately, these methods heat normal hypodermal tissues before heating deep tumors. Therefore, considering the damage to normal hypodermal tissues, it is extremely difficult to increase the tumor temperature to the therapeutic temperature for hyperthermia.
Furthermore, these heating methods have poor control over the tumor temperature.

On the other hand, ACMF heating has the following advantages over conventional heating methods: ${ }^{25-42}$ (1) ACMF penetrates deep into the tissue, and it can heat deep tumors without damaging normal hypodermal tissues; and (2) adjusting the $H$ and $f$ of ACMF allows for easy regulation of the tumor temperature. ${ }^{42-45}$ Therefore, ACMF is a suitable trigger for drug release. ACMF-responsive drug carriers enable the remote, on-demand release of anticancer drugs, which reducing the side effects possible in conventional treatment methods.

Herein, we present the synthesis of smart NPs that effectively produce heat in response to harmless $\operatorname{ACMF}\left(H=8 \mathrm{kA} \mathrm{m}^{-1}, f=230 \mathrm{kHz}, H f=1.8 \times 10^{9} \mathrm{~A} \mathrm{~m}^{-1}\right.$ $\mathrm{s}^{-1}$ ) and sequentially release doxorubicin (DOX), an anticancer drug. Furthermore, we report the in vivo therapeutic efficacy of combining MHT and chemotherapy using the above smart NPs for treating multiple myeloma, which remains an incurable malignancy.

\section{Results and Discussion}

\section{Synthesis and characterization of smart NPs}

We designed the ACMF-responsive smart NPs by combining the DOX and clustered $\mathrm{Fe}_{3} \mathrm{O}_{4}$ NPs core within a containing polymer with a glass-transition temperature $\left(T_{\mathrm{g}}\right)$ of $44^{\circ} \mathrm{C}$ (Fig. 1A). During exposure to the $\mathrm{ACMF}$, the inner $\mathrm{Fe}_{3} \mathrm{O}_{4} \mathrm{NPs}$ cluster produces heat until at least the $T_{\mathrm{g}}$, leading to the softening of the polymer phase, which allows the release of DOX.

The ACMF-responsive smart NPs were synthesized as follows (Fig. 2A). First, we polymerized pyrrole-3-carboxylic acid (PyCOOH) using iron (III) ion as a catalyst in an aqueous solution of DOX and polyvinyl alcohol (PVA) to synthesize DOX-containing carboxylic polypyrrole (DOX/PPyCOOH) NPs. In this reaction, DOX is contained within the NPs by the п-п interaction between PPyCOOH and DOX. In addition, the carboxylic acid groups of the DOX/PPyCOOH NPs are used for later surface modification. Second, we synthesized $\mathrm{Fe}_{3} \mathrm{O}_{4} \mathrm{NPs}$ within the DOX/PPyCOOH NPs by reducing part of the used iron (III) ions to iron (II) ions with hydrazine. Hydrazine also serves as a catalyst to promote the formation of $\mathrm{Fe}_{3} \mathrm{O}_{4}$ by making the $\mathrm{pH}$ of the solution alkaline. The products of this reaction are called $\mathrm{Fe}_{3} \mathrm{O}_{4} / \mathrm{DOX} / \mathrm{PPyCOOH}$ NPs. Finally, to increase the NP retention in the tumor, we modified the NPs with polyethylene glycol (PEG) and folic acid (FA) by the amidation reaction of $\mathrm{Fe}_{3} \mathrm{O}_{4} / \mathrm{DOX} / \mathrm{PPyCOOH} \mathrm{NPs}$ with amine- and FA-heterobifunctionalized PEG (FA-PEG-NH ${ }_{2}$ ). In particular, PEG prevents the 
phagocytosis by macrophages, and FA specifically binds to the folate receptors overexpressed in the cancer cells. ${ }^{46-49}$ The products obtained by this modification are called $\mathrm{Fe}_{3} \mathrm{O}_{4} /$ DOX/PPy-PEG-FA NPs.

The transmission electron microscope (TEM) images of the $\mathrm{Fe}_{3} \mathrm{O}_{4} /$ DOX/PPy-PEG-FA NPs confirm that the $\mathrm{Fe}_{3} \mathrm{O}_{4} \mathrm{NPs}$ are clustered. The $\mathrm{Fe}_{3} \mathrm{O}_{4}$ NPs have a mean particle size of $10.5 \mathrm{~nm}$, and the mean cluster size is $47.4 \mathrm{~nm}$ (Supplementary Material: Fig. S1†). Furthermore, the clustered $\mathrm{Fe}_{3} \mathrm{O}_{4} \mathrm{NPs}$ are coated with a layer of PPy-PEG-FA with a thickness of $\sim 10 \mathrm{~nm}$. Thus, the mean size of the $\mathrm{Fe}_{3} \mathrm{O}_{4}$ /DOX/PPy-PEG-FA NPs is $\sim 70 \mathrm{~nm}$.

The inorganic phase of the $\mathrm{Fe}_{3} \mathrm{O}_{4}$ /DOX/PPy-PEG-FA NPs is composed of single-phase $\mathrm{Fe}_{3} \mathrm{O}_{4}$ as shown by the X-ray diffraction (XRD) pattern (Supplementary Material: Fig. S2). The crystallite sizes are 15.5, 13.8, 17.5, 16.6 and $16.1 \mathrm{~nm}$, respectively, as determined from the Scherrer equation using the 220, 311, 400, 511 and 440 reflections. Thus, the average crystallite size is $15.9 \mathrm{~nm}$.

Supplementary Material: Fig. S3 shows the Fourier-transform infrared (FTIR) spectra of $\mathrm{PyCOOH}$, DOX, $\mathrm{Fe}_{3} \mathrm{O}_{4} /$ DOX/PPyCOOH NPs, and $\mathrm{Fe}_{3} \mathrm{O}_{4} / \mathrm{DOX} /$ PPy-PEG-FA NPs. In the $\mathrm{Fe}_{3} \mathrm{O}_{4} / \mathrm{DOX} / \mathrm{PPyCOOH} \mathrm{NP}$ spectrum, the bands corresponding to the amine of
DOX and PPyCOOH are observed at 3640-3310 $\mathrm{cm}^{-1} .{ }^{50}$ In addition, the bands attributed to the carboxylic acid of DOX and PPyCOOH are observed at 1790 and $1640 \mathrm{~cm}^{-1}$, respectively. In the $\mathrm{Fe}_{3} \mathrm{O}_{4} /$ DOX/PPy-PEG-FA NP spectrum, the bands attributed to the carboxylic acid of $\mathrm{PPyCOOH}$ disappear, indicating that the amidation between $\mathrm{Fe}_{3} \mathrm{O}_{4} / \mathrm{DOX} / \mathrm{PPyCOOH} \mathrm{NPs}$ and FA-PEG-NH $\mathrm{N}_{2}$ has occurred. Furthermore, the band attributed to the aromatic hydrocarbon of FA appears at $845 \mathrm{~cm}^{-1}$. These findings confirm that the NPs are successfully modified with FA and PEG.

The hydrodynamic diameters of the $\mathrm{Fe}_{3} \mathrm{O}_{4} /$ DOX/PPyCOOH NPs and $\mathrm{Fe}_{3} \mathrm{O}_{4} /$ DOX/PPy-PEG-FA NPs in water were $51 \pm 8$ and $67 \pm 13 \mathrm{~nm}$, respectively, as measured by dynamic light scattering (DLS) (Supplementary Material: Fig. S4). The hydrodynamic diameter of the $\mathrm{Fe}_{3} \mathrm{O}_{4} /$ DOX/PPy-PEG-FA NPs was larger than that of the $\mathrm{Fe}_{3} \mathrm{O}_{4} / \mathrm{DOX} / \mathrm{PPyCOOH} \mathrm{NPs}$ by $\sim 16 \mathrm{~nm}$ because of the FA and PEG modification. In addition, the hydrodynamic diameters of $\mathrm{Fe}_{3} \mathrm{O}_{4}$ /DOX/PPy-PEG-FA NPs are consistent with the size estimated from the TEM images. The zeta potentials of the $\mathrm{Fe}_{3} \mathrm{O}_{4} / \mathrm{DOX} / \mathrm{PPyCOOH} \mathrm{NPs}$ and $\mathrm{Fe}_{3} \mathrm{O}_{4}$ /DOX/PPy-PEG-FA NPs were -0.97 and -1.87 $\mathrm{mV}$, respectively.

A

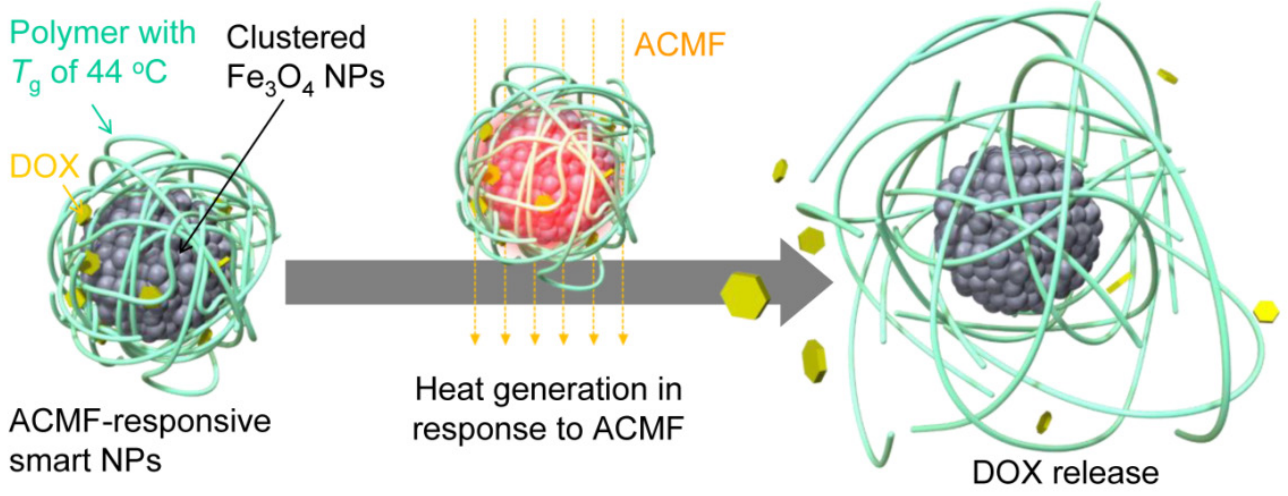

B

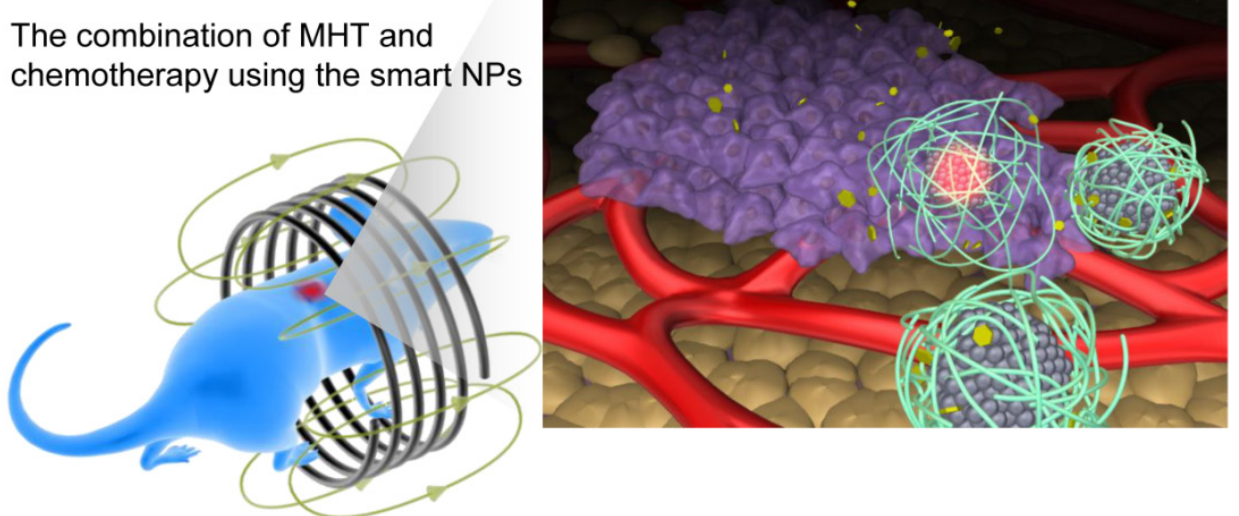

Figure I. (A) Illustration of smart NPs that produce heat in response to ACMF and sequentially release DOX. (B) Illustration of cancer treatment with the combination of MHT and chemotherapy using the smart NPs. 
A
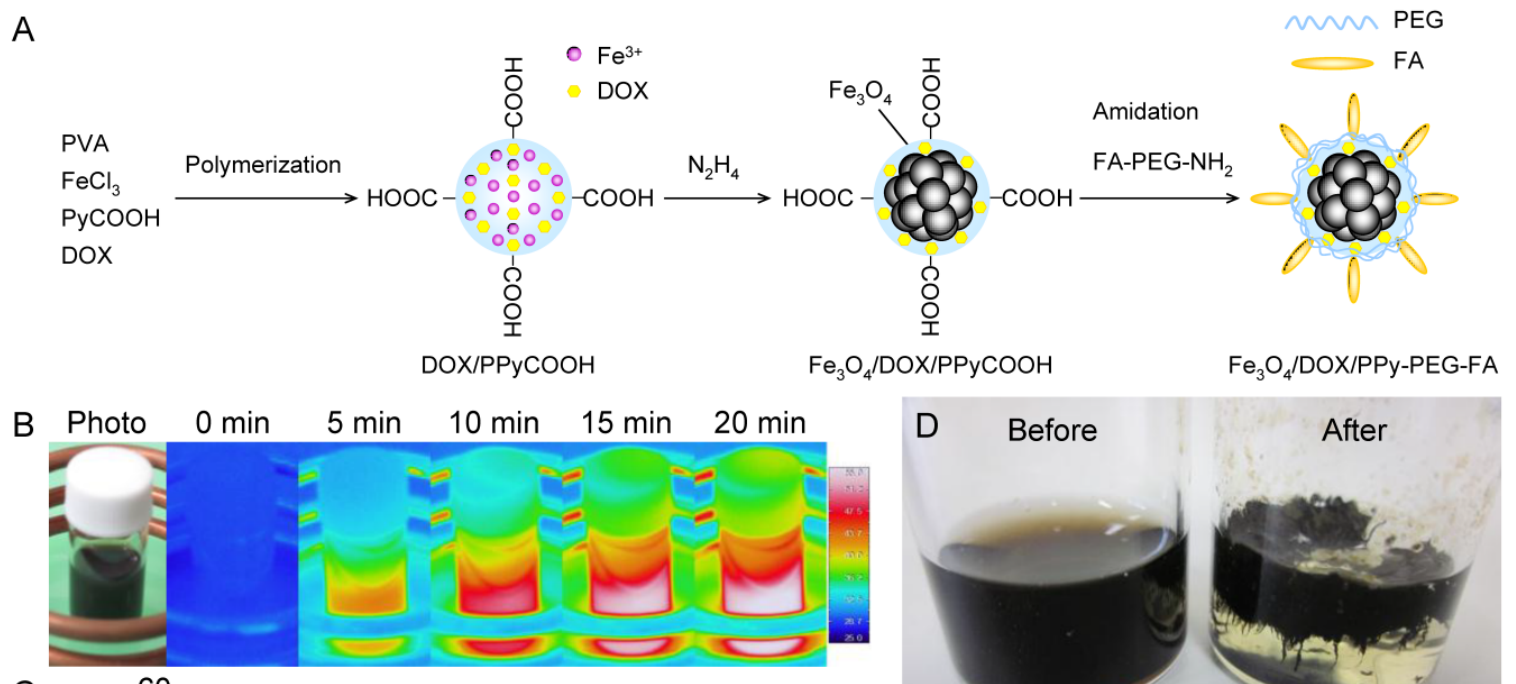

C
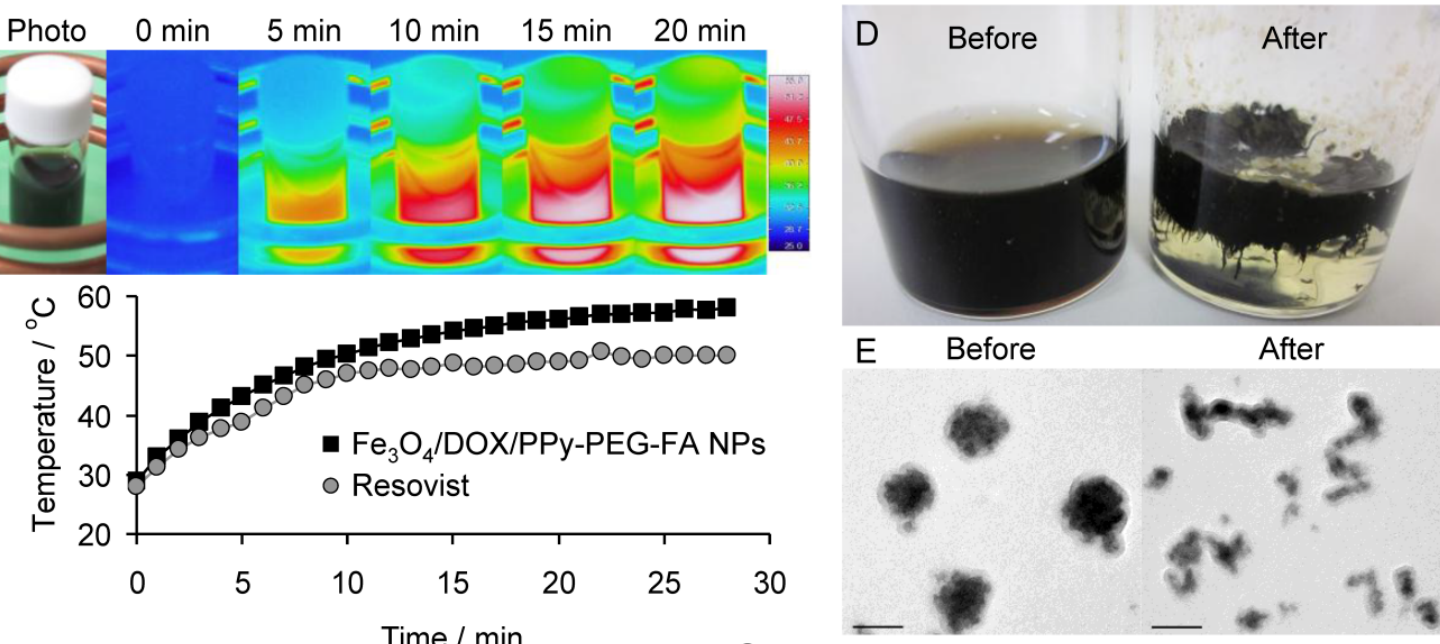

$\mathrm{F}$
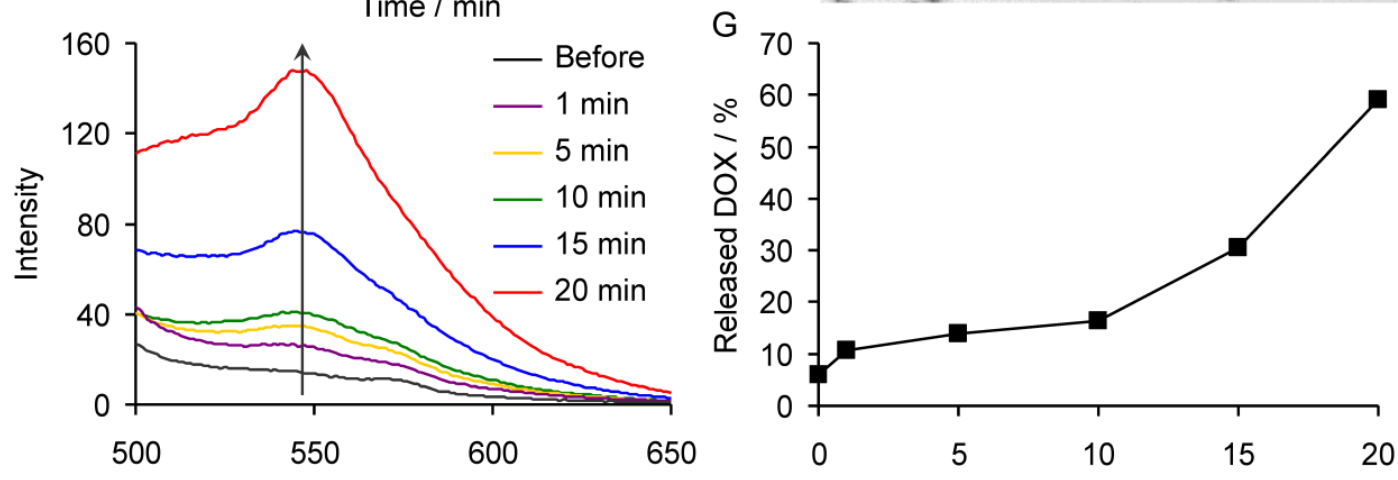

Wavelength / $\mathrm{nm}$

Time / min

Figure 2. (A) Schematic showing the synthesis of $\mathrm{Fe}_{3} \mathrm{O}_{4} / \mathrm{DOX} / \mathrm{PPy}$-PEG-FA NPs. (B) Photograph and thermal images of the aqueous dispersion of $\mathrm{Fe}_{3} \mathrm{O}_{4} / \mathrm{DOX} / \mathrm{PPy}$-PEG-FA NPs under ACMF. (C) Temperature change of the aqueous dispersion of $\mathrm{Fe}_{3} \mathrm{O}_{4} / \mathrm{DOX} / \mathrm{PPy}$-PEG-FA NPs with respect to ACMF exposure time. (D) Photographs and (E) TEM images of $\mathrm{Fe}_{3} \mathrm{O}_{4} / \mathrm{DOX} / \mathrm{PPy}$-PEG-FA NPs before and after the application of ACMF. (F) Fluorescence spectra of the supernatant of the aqueous dispersion of $\mathrm{Fe}_{3} \mathrm{O}_{4} / \mathrm{DOX} / \mathrm{PPy}$-PEG-FA NPs before and after the application of ACMF. (G) Proportion of DOX released from $\mathrm{Fe}_{3} \mathrm{O}_{4} / \mathrm{DOX} / \mathrm{PPy}$-PEG-FA NPs with respect to ACMF exposure time.

The organic phase proportions in the $\mathrm{Fe}_{3} \mathrm{O}_{4} /$ DOX/PPyCOOH NPs and $\mathrm{Fe}_{3} \mathrm{O}_{4} /$ DOX/PPy-PEG-FA NPs were 57 and $80 \%$, respectively, as measured by thermogravimetry (TG) (Supplementary Material: Fig. S5). Thus, the fraction of FA-PEG in the $\mathrm{Fe}_{3} \mathrm{O}_{4}$ / DOX/PPy-PEG-FA NPs is estimated to be $23 \%$. Based on this estimate, the abundance of FA-PEG is $2.3 \times 10^{-5} \mathrm{~mol} / \mathrm{g}$.

The differential scanning calorimetry (DSC) curve of the $\mathrm{Fe}_{3} \mathrm{O}_{4} /$ DOX/PPy-PEG-FA NPs demonstrates that the $T_{\mathrm{g}}$ was $44^{\circ} \mathrm{C}$ (Supplementary Material: Fig. S6).

We estimated the DOX content in the $\mathrm{Fe}_{3} \mathrm{O}_{4}$ /DOX/PPy-PEG-FA NPs from the absorbance at the wavelength of $480 \mathrm{~nm}$, which is attributed to the light absorption by DOX, using the calibration curve method (Supplementary Material: Fig. S7). This evaluation demonstrated that the $\mathrm{Fe}_{3} \mathrm{O}_{4} / \mathrm{DOX} / \mathrm{PPy}-$ PEG-FA NPs had a DOX content of $42.6 \mathrm{mg} / \mathrm{g}$.

The magnetic properties of the $\mathrm{Fe}_{3} \mathrm{O}_{4} /$ DOX/PPy-PEG-FA NPs were measured using a vibrating sample magnetometer (VSM) at room temperature. The $M_{\mathrm{s}}$ of the $\mathrm{Fe}_{3} \mathrm{O}_{4} /$ DOX/PPy-PEG-FA NPs was $16.7 \mathrm{emu} / \mathrm{g}$ (Supplementary Material: Fig. S8A). The corrected $M_{\mathrm{S}}$ is $83.5 \mathrm{emu} / \mathrm{g}$ because the proportion of the $\mathrm{Fe}_{3} \mathrm{O}_{4}$ phase in the $\mathrm{Fe}_{3} \mathrm{O}_{4} / \mathrm{DOX} /$ PPy-PEG-FA NPs was $20 \%$ as shown from the TG result (Supplementary Material: Fig. S6). Furthermore, the $\mathrm{Fe}_{3} \mathrm{O}_{4} /$ DOX/PPy-PEG-FA NPs have a coercivity $\left(H_{c}\right)$ of 15.2 Oe and a remanent magnetization 
$\left(M_{\mathrm{r}}\right)$ of $1.25 \mathrm{emu} / \mathrm{g}$ (Supplementary Material: Fig. $\mathrm{S} 8 \mathrm{~B})$, indicating that they are ferromagnetic. $\mathrm{Fe}_{3} \mathrm{O}_{4}$ NPs with a particle size of $\sim 15 \mathrm{~nm}$ generally exhibit superparamagnetism, which shows neither $H_{\mathrm{c}}$ nor $M_{\mathrm{r}}$. Actually, both $H_{\mathrm{c}}$ and $\mathrm{M}_{\mathrm{r}}$ of $\mathrm{Fe}_{3} \mathrm{O}_{4} \mathrm{NPs}$ synthesized by mixing $\mathrm{FeCl}_{3}$ with hydrazine, which is the similar method as $\mathrm{Fe}_{3} \mathrm{O}_{4} /$ DOX/PPy-PEG-FA NPs, are zero (Figs. S8C and S8D). However, the clustering of $\mathrm{Fe}_{3} \mathrm{O}_{4}$ NPs produces strong magnetic dipole-dipole attractions between the $\mathrm{Fe}_{3} \mathrm{O}_{4}$ NPs, which induces ferromagnetic behavior (Figs. S8A and S8B). ${ }^{51}$ Furthermore, ferromagnetic NPs exhibit higher SARs than superparamagnetic NPs. ${ }^{42}$ In particular, ferromagnetic NPs with a $H_{\mathrm{c}}$ of $\sim 15$ Oe represent the maximum SAR, which is five times higher than that of superparamagnetic NPs. ${ }^{43}$ Therefore, $\mathrm{Fe}_{3} \mathrm{O}_{4} / \mathrm{DOX} /$ PPy-PEG-FA NPs are more useful for MHT than typical superparamagnetic NPs.

We evaluated the SAR of the $\mathrm{Fe}_{3} \mathrm{O}_{4} / \mathrm{DOX} /$ PPy-PEG-FA NPs in water and compared it to the SAR of Resovist ${ }^{\circledR}$, a clinical MRI contrast agent, by exposing the aqueous solutions $(3 \mathrm{mg} / \mathrm{mL})$ of $\mathrm{Fe}_{3} \mathrm{O}_{4} /$ DOX/PPy-PEG-FA NPs and Resovist ${ }^{\circledR}$ to ACMF. Both the $\mathrm{Fe}_{3} \mathrm{O}_{4}$ /DOX/PPy-PEG-FA NPs and Resovist ${ }^{\circledR}$ generated heat and increased the water temperature by $\sim 29$ and $\sim 22^{\circ} \mathrm{C}$ for $25 \mathrm{~min}$, respectively (Fig. 2B and 2C). The SAR normalized to the $\mathrm{Fe}_{3} \mathrm{O}_{4}$ amount is calculated by

$$
\operatorname{SAR}=(C / m)(\mathrm{d} T / \mathrm{d} t),
$$

where $C$ is the specific heat capacity of water, $m$ is the concentration $\left(\mathrm{g} / \mathrm{L}\right.$ of $\left.\mathrm{Fe}_{3} \mathrm{O}_{4}\right)$ of magnetic NPs in solution, and $\mathrm{d} T / \mathrm{d} t$ is the slope of the curve for the first minute of ACMF exposure. ${ }^{1}$ The SAR average and minimum values of the $\mathrm{Fe}_{3} \mathrm{O}_{4} / \mathrm{DOX} / \mathrm{PPy}$-PEG-FA NPs and Resovist ${ }^{\circledR}$ were 487, 336, 360 and $236 \mathrm{~W} / \mathrm{g}$, respectively. These findings demonstrated that the $\mathrm{Fe}_{3} \mathrm{O}_{4} /$ DOX/PPy-PEG-FA NPs have a significantly higher ACMF-to-heat conversion efficiency than Resovist ${ }^{\circledR}$.

The photographs and TEM images of the $\mathrm{Fe}_{3} \mathrm{O}_{4} /$ DOX/PPy-PEG-FA NPs before and after the ACMF exposure show that the polymer phase of the $\mathrm{Fe}_{3} \mathrm{O}_{4} /$ DOX/PPy-PEG-FA NPs is softened by the ACMF exposure. This confirms that the $\mathrm{Fe}_{3} \mathrm{O}_{4} /$ DOX/PPy-PEG-FA NPs were heated to the $T_{\mathrm{g}}$ $\left(\sim 44^{\circ} \mathrm{C}\right)$ by the heat generation of the $\mathrm{Fe}_{3} \mathrm{O}_{4}$ phase (Fig. 2D and 2E).

After exposure to the ACMF, we determined the amount of DOX released from the $\mathrm{Fe}_{3} \mathrm{O}_{4} / \mathrm{DOX} /$ PPy-PEG-FA NPs in aqueous solution $(0.25 \mathrm{mg} / \mathrm{mL})$ by measuring the fluorescence intensity of the supernatant DOX, which was collected by centrifugation. The fluorescence intensity of the supernatant DOX increased with ACMF exposure time (Fig. 2F). Based on the calibration curve (Supplementary Material: Fig. S9A), the $\mathrm{Fe}_{3} \mathrm{O}_{4}$ /DOX/PPy-PEG-FA NPs released 6.3 $\mu \mathrm{g} / \mathrm{mL}$ of DOX after 20 min of exposure (Fig. S9B), indicating that $\sim 60 \%$ of the DOX content in the $\mathrm{Fe}_{3} \mathrm{O}_{4} / \mathrm{DOX} / \mathrm{PPy}-\mathrm{PEG}-\mathrm{FA}$ NPs was released by the ACMF application (Fig. 2G). Furthermore we investigated the relationship between the proportion of DOX released from $\mathrm{Fe}_{3} \mathrm{O}_{4} / \mathrm{DOX} / \mathrm{PPy}-\mathrm{PEG}-\mathrm{FA}$ NPs and temperature (Fig. S9C). $\mathrm{Fe}_{3} \mathrm{O}_{4} / \mathrm{DOX} / \mathrm{PPy}$-PEGFA NPs began to release DOX at $39^{\circ} \mathrm{C}$, and then the proportion of released DOX was drastically increased with temperature. More than $60 \%$ of the DOX content in the $\mathrm{Fe}_{3} \mathrm{O}_{4} /$ DOX/PPy-PEG-FA NPs was released at $T_{\mathrm{g}}\left(\sim 44^{\circ} \mathrm{C}\right)$, and the proportion of released DOX reached about $90 \%$ at $46^{\circ} \mathrm{C}$. Generally, DOX leaks from tumor in the case of rapid intratumoral injection. The $\mathrm{Fe}_{3} \mathrm{O}_{4} /$ DOX/PPy-PEG-FA NPs is useful for preventing the leakage of DOX from tumor because they gradually release DOX.

\section{In vivo therapeutic efficacy}

To assess the in vivo therapeutic efficacy of the combination of MHT and chemotherapy, we injected the mice bearing subcutaneous xenograft tumors derived from the RPMI8226 multiple myeloma cell line intratumorally with the $\mathrm{Fe}_{3} \mathrm{O}_{4} / \mathrm{DOX} / \mathrm{PPy}$-PEG-FA NPs $(5 \mathrm{mg} / \mathrm{kg})$ and then exposed the mice to the ACMF (Fig. 1B). Fig. 3A shows the thermal image of the mice exposed to the ACMF for $20 \mathrm{~min}$ after the injection of $\mathrm{Fe}_{3} \mathrm{O}_{4} /$ DOX/PPy-PEG-FA NPs. The tumor was locally heated to the therapeutic temperature for hyperthermia (above $42.5^{\circ} \mathrm{C}$ ), although the normal tissues were regulated at the survival temperature for cells. Fig. 3B shows the change of the tumor temperature of the mice injected with $\mathrm{Fe}_{3} \mathrm{O}_{4} / \mathrm{DOX} /$ PPy-PEG-FA NPs, DOX-free NPs (designated as $\mathrm{Fe}_{3} \mathrm{O}_{4} /$ PPy-PEG-FA NPs), and no NPs with respect to the ACMF exposure time $(n=5)$. The tumor temperature of the mice injected with $\mathrm{Fe}_{3} \mathrm{O}_{4} / \mathrm{DOX} /$ PPy-PEG-FA NPs or $\mathrm{Fe}_{3} \mathrm{O}_{4}$ / PPy-PEG-FA NPs drastically increased immediately after the application of the ACMF, and then it gradually increased with time. After the $7 \mathrm{~min}$ of ACMF exposure, both of these tumor temperatures reached $44^{\circ} \mathrm{C}$. The unadministered mice exposed to the ACMF for 20 min showed little difference in the tumor temperature, indicating that the ACMF has only a limited effect on the elevation of body temperature. The follow-up photographs show that the mouse treated with $\mathrm{Fe}_{3} \mathrm{O}_{4} / \mathrm{DOX} / \mathrm{PPy}-$ PEG-FA NPs has a scab on their tumors 4 days after treatment, and their tumors completely disappear within 8 days (Fig. 3C). 
A

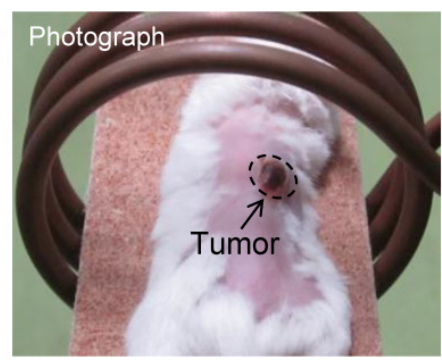

B

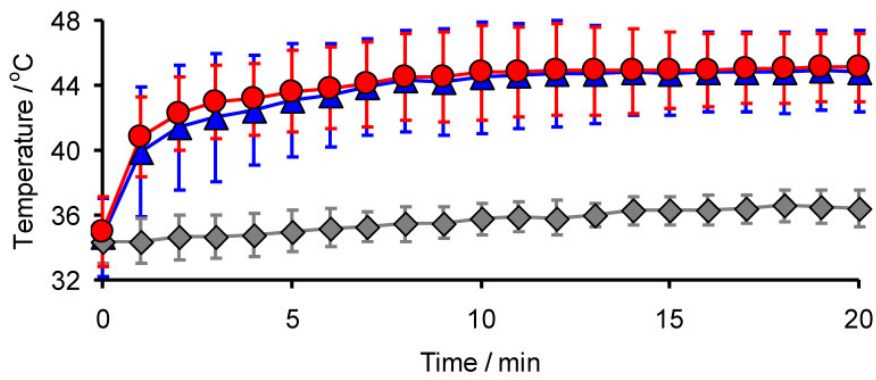

D

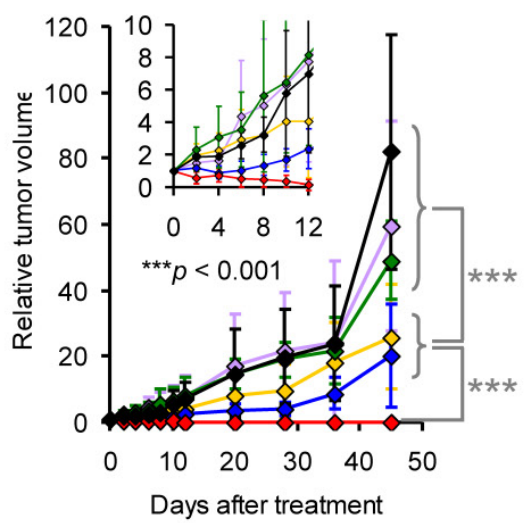

E

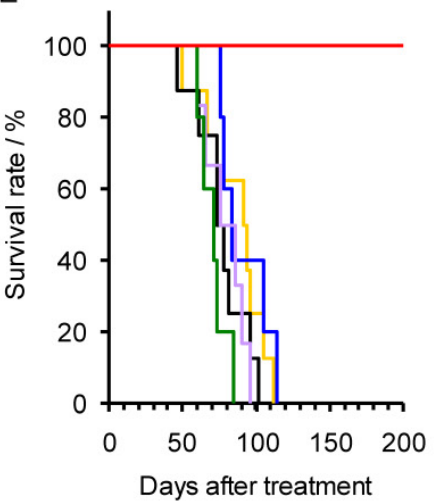

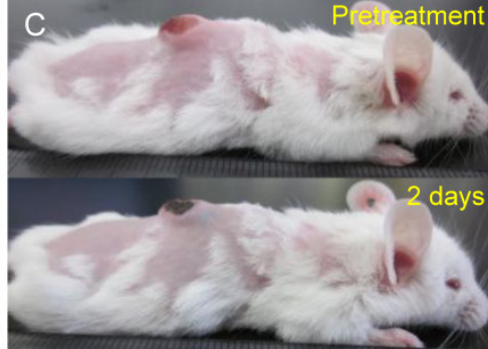
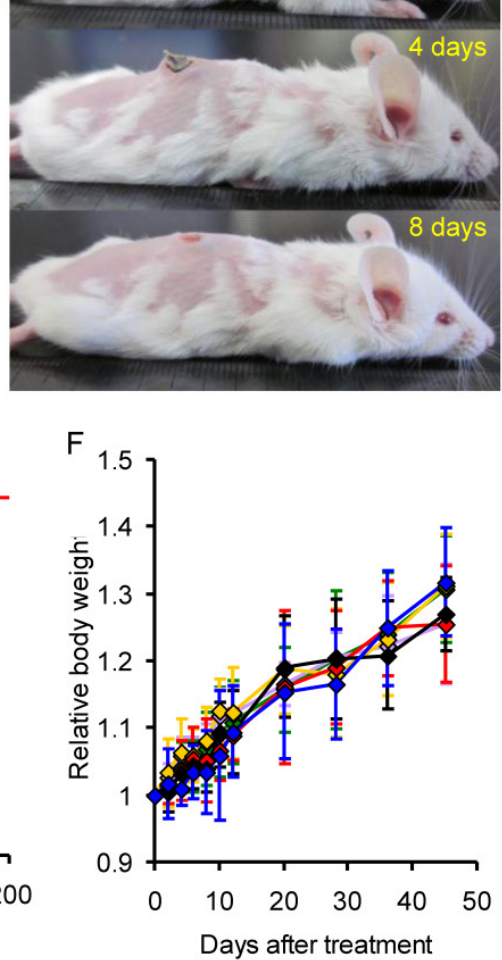

G No treatment $\mathrm{Fe}_{3} \mathrm{O}_{4} /$ DOX/PPy-PEG-FA ACMF

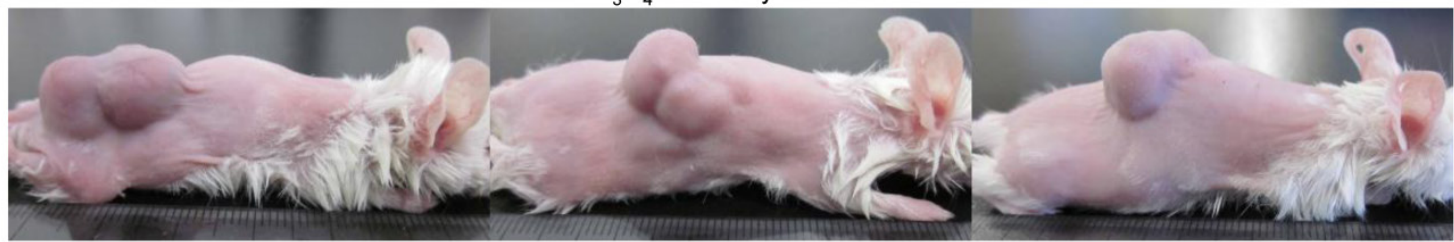

Chemotherapy MHT MHT + chemotherapy

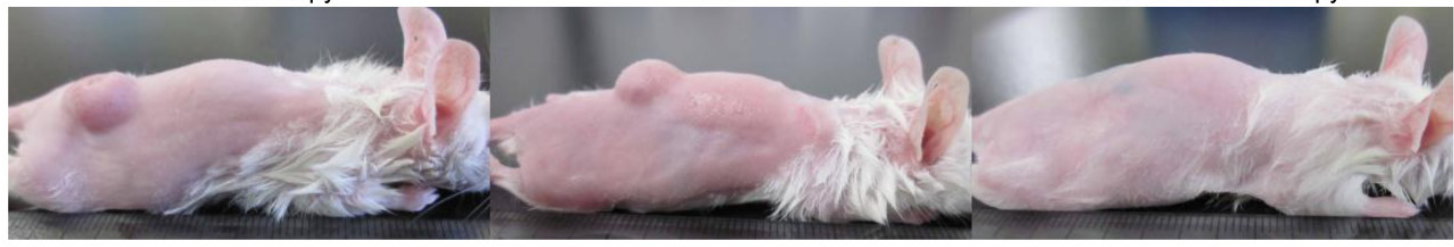

Figure 3. (A) Photograph and thermal image of a mouse exposed to ACMF for 20 min after injection with $\mathrm{Fe}_{3} \mathrm{O}_{4} / \mathrm{DOX} / \mathrm{PPy}-\mathrm{PEG}-\mathrm{FA}$ NPs. (B) Average change of the tumor temperature of the mice injected with $\mathrm{Fe}_{3} \mathrm{O}_{4} / \mathrm{DOX} / \mathrm{PPy}$-PEG-FA NPs, Fe $\mathrm{O}_{4} / \mathrm{PPy}$-PEG-FA NPs, and no NPs with respect to ACMF exposure time $(n=5)$. (C) Follow-up photographs of mouse exposed to ACMF for 20 min after injection with $\mathrm{Fe}_{3} \mathrm{O}_{4} / \mathrm{DOX} / \mathrm{PPy}-\mathrm{PEG}-\mathrm{FA}$ NPs. Change of (D) tumor volume, (E) survival rate, and (F) body weight: non-treated mice (black), mice treated with chemotherapy (yellow), mice exposed to ACMF (green), mice injected with $\mathrm{Fe}_{3} \mathrm{O}_{4} / \mathrm{DOX} / \mathrm{PPy}$-PEG-FA NPs intratumorally (purple), mice treated with MHT (blue), and mice treated with the combination of MHT and chemotherapy (red). The inset in Fig. 3D shows the magnified view for the first 12 days after treatment. (G) Photographs of non-treated mice, mice treated with chemotherapy, mice exposed to ACMF, mice injected with $\mathrm{Fe}_{3} \mathrm{O}_{4} / \mathrm{DOX} / \mathrm{PPy}-\mathrm{PEG}$-FA NPs intratumorally, mice treated with MHT, and mice treated with the combination of MHT and chemotherapy 45 days after treatment.

Furthermore, we compared the tumor volume, survival rate, and the body weight of the mice exposed to the ACMF after intratumoral injection of $\mathrm{Fe}_{3} \mathrm{O}_{4} /$ DOX/PPy-PEG-FA NPs (designated as mice treated with the combination of MHT and chemo- therapy) with those of the control groups: non-treated mice; mice injected with DOX intratumorally (designated as mice treated with chemotherapy); mice exposed to ACMF; mice injected with $\mathrm{Fe}_{3} \mathrm{O}_{4}$ /DOX/PPy-PEG-FA NPs intratumorally; mice 
exposed to ACMF after the intratumoral injection of $\mathrm{Fe}_{3} \mathrm{O}_{4}$ /PPy-PEG-FA NPs (designated as mice treated with MHT) (Fig. 3D, 3E, and 3F). Forty-five days after treatment, the tumor volume of the mice treated with chemotherapy or MHT was significantly smaller than those of the non-treated mice, the mice exposed to ACMF, and the mice injected with $\mathrm{Fe}_{3} \mathrm{O}_{4}$ /DOX/ PPy-PEG-FA NPs (Fig. 3D). Thus, chemotherapy and MHT inhibit the tumor growth, but they cannot cure the tumor completely. For the mice treated with the combination of MHT and chemotherapy, the tumor volume gradually decreased as time passes and it reached zero within 12 days after treatment as shown in the inset of Fig. 3D. The tumor volume remained in zero 45 days after treatment (Fig. 3D), indicating that the combination of MHT and chemotherapy prevented recurrence and completely cured the tumor. The photographs 45 days after treatment also show that both MHT and chemotherapy inhibited the tu- mor growth, but the combination of MHT and chemotherapy eliminates the tumor completely (Fig. 3G). Furthermore, the survival rate for mice treated with the combination of MHT and chemotherapy was $100 \% 200$ days after the treatment, while the non-treated mice, the mice exposed to ACMF, and the mice injected with $\mathrm{Fe}_{3} \mathrm{O}_{4}$ /DOX/PPy-PEG-FA NPs all died within about 100 days (Fig. 3E). MHT and chemotherapy somewhat prolonged the survival period. There was no significant difference in the body weight between the groups (Fig. 3F).

We investigated how the therapeutic efficacy was enhanced from the combination of MHT and chemotherapy using histological analyses of the tumors $24 \mathrm{~h}$ after treatment. In the non-treated mice, the mice exposed to ACMF, and the mice injected with $\mathrm{Fe}_{3} \mathrm{O}_{4}$ /DOX/PPy-PEG-FA NPs, the viable cancer cells were densely packed in the tumors as shown in region V (Fig. 4).

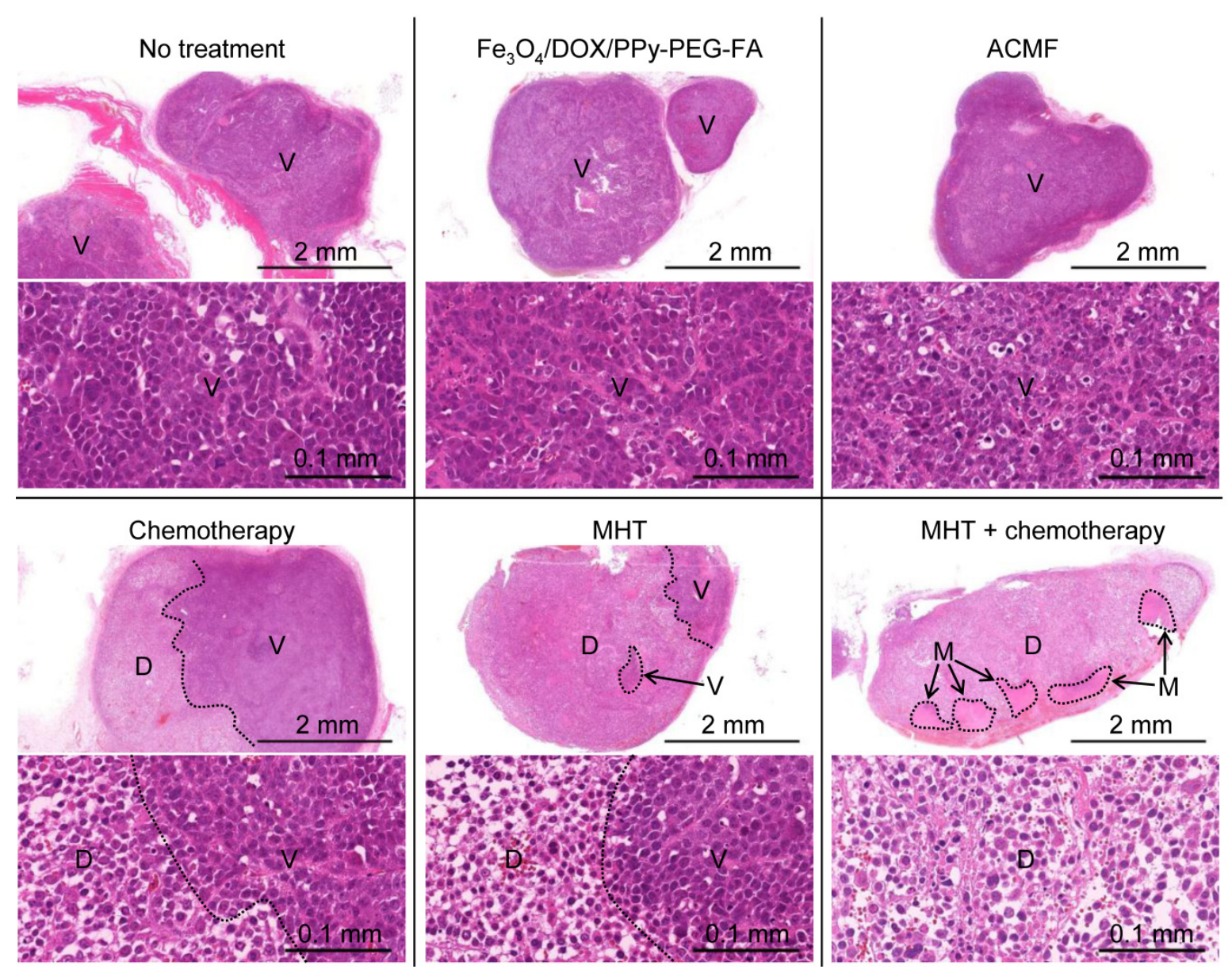

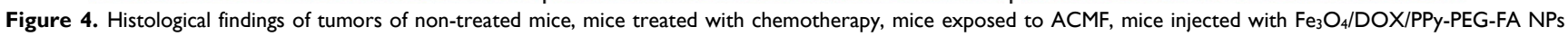
intratumorally, mice treated with $\mathrm{MHT}$, and mice treated with the combination of MHT and chemotherapy $24 \mathrm{~h}$ after treatment: viable tumor tissue ( $\mathrm{V}$ ); destroyed tumor tissue (D); normal muscle tissue (M) 


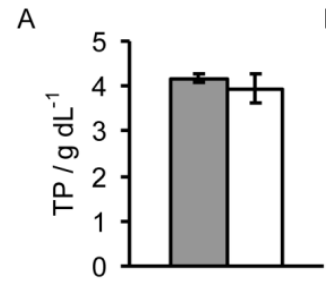

B
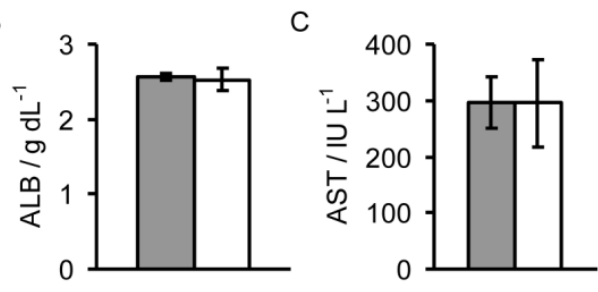

D

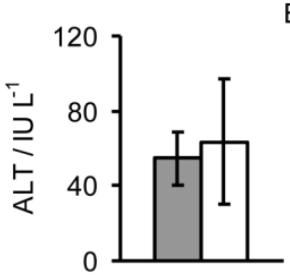

E
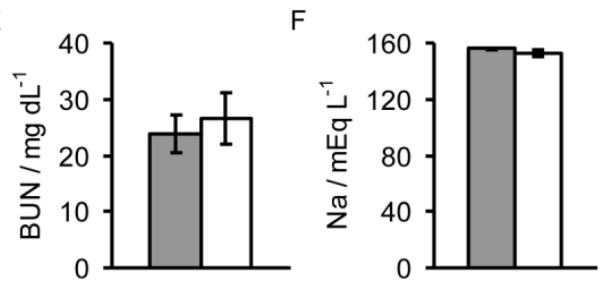

G
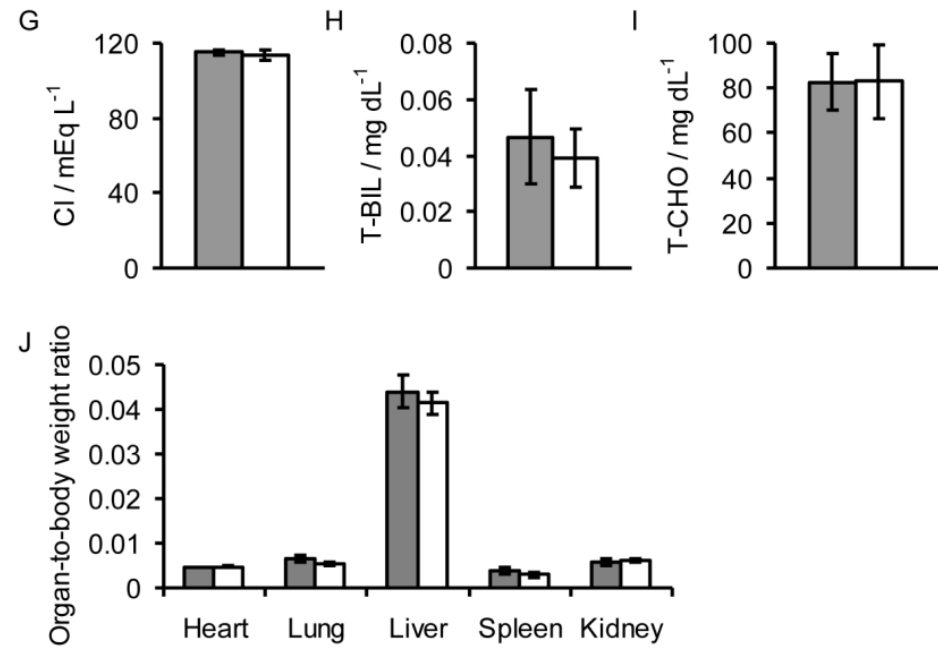

Figure 5. Biochemical assays in the sera and organ-to-body weight ratios of mice injected with $\mathrm{Fe}_{3} \mathrm{O}_{4} / \mathrm{DOX} / \mathrm{PPy}-\mathrm{PEG}-\mathrm{FA} \mathrm{NPs}$ (gray) and non-treated mice (white). The following measurements were taken $24 \mathrm{~h}$ after injection: (A) total protein (TP), (B) albumen (ALB), (C) asparatate aminotransferase (AST), (D) alanine aminotransferase (ALT), (E) blood urea nitrogen (BUN), (F) sodium $(\mathrm{Na}),(\mathrm{G})$ chlorine $(\mathrm{Cl}),(\mathrm{H})$ total bilirubin (T-BIL), and (I) total cholesterol (T-CHO) values, and the (J) organ-to-body weight ratios.

For the mice treated with chemotherapy, the cancer cells were only partly destroyed as shown in the region $\mathrm{D}$, indicating that DOX did not spread throughout the tumor. MHT destroyed cancer cells in a broader tumor area than that of chemotherapy; however, all cancer cells were not destroyed. Furthermore, MHT shrank the cytoplasm of the cancer cells and widened the space between cancer cells (Supplementary Material: Fig. S10). The similar phenomenon has been observed in light-mediated treatment. ${ }^{52}$ For the mice treated with the combination of MHT and chemotherapy, the cancer cells were fully destroyed throughout the tumor. This probably occurred because MHT widened the space between the cancer cells, allowing DOX to spread throughout the tumor. Furthermore, the combination of MHT and chemotherapy significantly widened the space between the cancer cells compared to only MHT (Supplementary Material: Fig. S10), which indicates that the combination treatment caused more serious damage to the tumor. Thus, the combination of MHT and chemotherapy can more effectively destroy cancer cells than MHT. The data from the tumor volume, survival rate, and the histological findings demonstrates that the combination of MHT and chemotherapy creates a synergistic effect, which enhances the therapeutic efficacy. Moreover, the muscle tissues extended to the tumor suffered no damage from the combination of MHT and chemotherapy (Supplementary Material: Fig. S11). Thus, the combination of MHT and chemotherapy destroys the tumor without damaging normal tissues. Furthermore, Prussian blue nuclear fast red staining of the tumor section of the mouse treated with a combination of MHT and chemotherapy shows that $\mathrm{Fe}_{3} \mathrm{O}_{4} /$ DOX/PPy-PEG-FA NPs are distributed throughout the entire tumor and their distribution is relatively uniform. (Supplementary Material: Fig. S12).

\section{Toxicity assay}

To assess the toxicity of the $\mathrm{Fe}_{3} \mathrm{O}_{4} / \mathrm{DOX} /$ PPy-PEG-FA NPs, we measured the organ-to-body weight ratio, and the amount of total protein (TP), albumen (ALB), asparatate aminotransferase (AST), alanine aminotransferase (ALT), blood urea nitrogen (BUN), $\mathrm{Na}$, $\mathrm{Cl}$, total bilirubin (T-BIL), and total cholesterol (T-CHO) in the sera of the mice $24 \mathrm{~h}$ after intravenous injection of the NPs. There was no significant difference in the values between the mice injected with NPs and the non-treated mice (Fig. 5). Thus, $\mathrm{Fe}_{3} \mathrm{O}_{4}$ /DOX/PPy-PEG-FA NPs have no significant toxicity.

\section{Conclusions}

The $\mathrm{Fe}_{3} \mathrm{O}_{4} /$ DOX/PPy-PEG-FA NPs effectively produced heat when exposed to a harmless ACMF and sequentially released DOX. MHT or chemotherapy could not cure the tumor, but the treatment inhibited the tumor growth. On the other hand, the combination of MHT and chemotherapy using the $\mathrm{Fe}_{3} \mathrm{O}_{4}$ /DOX/PPy-PEG-FA NPs completely cured the tumor without recurrence of malignancy. The combination of MHT and chemotherapy destroyed the cancer cells in the entire tumor, causing more serious damage to tumor than MHT. Thus, the combination of MHT and chemotherapy creates a synergistic effect, which destroys the cancer cells. Furthermore, the $\mathrm{Fe}_{3} \mathrm{O}_{4} /$ DOX/PPy-PEG-FA NPs have no significant toxicity. In this study, we administered the $\mathrm{Fe}_{3} \mathrm{O}_{4} /$ DOX/PPy-PEG-FA NPs to the mice by intratumoral injection as the first step for investigating the 
therapeutic efficacy of the combination of MHT and chemotherapy using the $\mathrm{Fe}_{3} \mathrm{O}_{4} / \mathrm{DOX} / \mathrm{PPy}-\mathrm{PEG}-\mathrm{FA}$ NPs. In the future, we will assess the therapeutic efficacy by intravenous injection of the $\mathrm{Fe}_{3} \mathrm{O}_{4} / \mathrm{DOX} /$ PPy-PEG-FA NPs.

\section{Experimental}

\section{Materials}

PyCOOH, hydrazine monohydrate, 1-(3-dimethylaminopropyl)-3-ethylcarbodiimide hydrochloride (EDAC), and N-hydroxysuccinimide (NHS) were purchased from Tokyo Chemical Industry (Tokyo). PVA $\left(M_{\mathrm{W}}=40,000\right)$ and iron (III) chloride hexahydrate were purchased from Sigma-Aldrich (MO, USA). DOX was purchased from Toronto Research Chemicals Inc. (NY, USA). FA-PEG-NH $2\left(M_{\mathrm{W}}=10,000\right)$ was purchased from Nanocs (NY, USA).

\section{Synthesis of $\mathrm{Fe}_{3} \mathrm{O}_{4} / \mathrm{DOX} / \mathrm{PPyCOOH} \mathrm{NPs}$}

$\mathrm{DOX} / \mathrm{PPyCOOH}$ NPs were synthesized by reference to the synthesis method of DOX-free PPy NPs without carboxylic acid. ${ }^{53}$ PVA $(0.94 \mathrm{mmol})$ was dissolved in distillated water $(10 \mathrm{~mL})$ at $85^{\circ} \mathrm{C}$ for $60 \mathrm{~min}$. After cooling the aqueous solution of PVA to room temperature, iron (III) chloride hexahydrate (0.32 mmol) was added to the solution, which was then stirred at room temperature for $1 \mathrm{~h}$. DOX $(3.5 \mathrm{mmol})$ and $\mathrm{PyCOOH}(0.28 \mathrm{mmol})$ were added to the above solution, which was then stirred at room temperature for $72 \mathrm{~h}$ in the dark. Hydrazine monohydrate (10.3 mmol) was added to the solution of DOX/PPyCOOH NPs, which was then stirred for $24 \mathrm{~h}$ in the dark. ${ }^{12,42-45,54}$ The product was collected from the dispersion by centrifugation $(20,000 \mathrm{~g}, 5 \mathrm{~h})$ and redispersed in distillated water. This sequence was repeated three times.

\section{Synthesis of $\mathrm{Fe}_{3} \mathrm{O}_{4} / \mathrm{DOX} / \mathrm{PPy}$-PEG-FA NPs}

FA-PEG-NH $\mathrm{N}_{2}(20 \mathrm{nmol}), \mathrm{EDAC}(20 \mathrm{nmol})$, and NHS (20 nmol) were added to the aqueous dispersion of $\mathrm{Fe}_{3} \mathrm{O}_{4} / \mathrm{DOX} / \mathrm{PPyCOOH} \mathrm{NPs}$, which was then stirred at room temperature for $24 \mathrm{~h}$ in the dark. The product was collected from the dispersion by centrifugation $(20,000 \mathrm{~g}, 5 \mathrm{~h})$ and redispersed in distillated water. This sequence was repeated three times.

\section{Characterization}

The size and shape of $\mathrm{Fe}_{3} \mathrm{O}_{4} /$ DOX/PPy-PEG-FA NPs were observed by TEM (H-760, Hitachi, Tokyo). The hydrodynamic diameter and zeta potential were measured by DLS (NICOMP 380 ZLS, Showa Denko, Tokyo). The FTIR spectra were recorded with a FTIR spectrometer (Nexus 470, Nicolet, Madison, WI). The amount of organic phase was measured using TG (Thermo plus EVO TG8120, Rigaku, Tokyo, Japan) at a heating rate of $10^{\circ} \mathrm{C} / \mathrm{min}$ from room temperature to $800^{\circ} \mathrm{C}$ under an oxygen atmosphere. The crystalline phases were analyzed by XRD using CuKa radiation with a monochromator (Rigaku SmartLab, Rigaku, Tokyo). The $T_{\mathrm{g}}$ was measured by DSC (TA Instruments. Japan, Tokyo). The magnetic properties were measured with a vibrating sample magnetometer (Type 5, Toei Kogyo, Tokyo) at room temperature. For comparison, we synthesized uncoated $\mathrm{Fe}_{3} \mathrm{O}_{4}$ NPs by mixing iron (III) chloride hexahydrate $(0.32 \mathrm{mmol})$ with hydrazine monohydrate $(10.3 \mathrm{mmol})$, which is the similar method as $\mathrm{Fe}_{3} \mathrm{O}_{4}$ /DOX/PPy-PEG-FA NPs.

\section{Estimation of DOX content in $\mathrm{Fe}_{3} \mathrm{O}_{4} / \mathrm{DOX} / \mathrm{PPy}$-PEG-FA NPs}

The absorbance of the aqueous dispersion of $\mathrm{Fe}_{3} \mathrm{O}_{4} / \mathrm{DOX} / \mathrm{PPy}$-PEG-FA NPs $(0.5 \mathrm{mg} / \mathrm{mL})$ was measured using an ultraviolet-visible (UV-Vis) spectrophotometer (U-3000, Hitachi, Tokyo). To prepare the calibration curve, the absorbance of DOX was measured at various concentrations $(0.001,0.025,0.05$, 0.1 , and $0.2 \mathrm{mg} / \mathrm{mL}$ ). The DOX content in $\mathrm{Fe}_{3} \mathrm{O}_{4} /$ DOX/PPy-PEG-FA NPs was determined by substituting the absorbance of the aqueous dispersion of $\mathrm{Fe}_{3} \mathrm{O}_{4}$ /DOX/PPy-PEG-FA NPs in the calibration curve.

\section{The heat generation of $\mathrm{Fe}_{3} \mathrm{O}_{4} / \mathrm{DOX} / \mathrm{PPy}$-PEG-FA NPs in water}

The aqueous dispersions ( $3 \mathrm{mg} / \mathrm{mL}$ ) of $\mathrm{Fe}_{3} \mathrm{O}_{4} /$ DOX/PPy-PEG-FA NPs and Resovist were placed in an ACMF with $H=8 \mathrm{kA} \mathrm{m}^{-1}$ and $f=230 \mathrm{kHz}$ ( $H f=1.8 \times 10^{9} \mathrm{~A} \mathrm{~m}^{-1} \mathrm{~s}^{-1}$ ) for $20 \mathrm{~min}$. An ACMF was generated using a transistor inverter with field coils (2.4 kW, EasyHeat, Ambrell, NY). Thermal images were taken using a Thermograph (Thermo Gear G100EX, NEC Avio Infrared Technologies, Tokyo). The SAR values of $\mathrm{Fe}_{3} \mathrm{O}_{4} / \mathrm{DOX} / \mathrm{PPy}$-PEG-FA NPs and Resovist normalized to the $\mathrm{Fe}_{3} \mathrm{O}_{4}$ amounts were calculated according to the following equation:

$$
\text { SAR }=(C / m)(\mathrm{d} T / \mathrm{d} t),
$$

where $C$ is the specific heat capacity of water, $m$ is the concentration $\left(\mathrm{g} / \mathrm{L}\right.$ of $\left.\mathrm{Fe}_{3} \mathrm{O}_{4}\right)$ of the magnetic NPs in solution, and $\mathrm{dT} / \mathrm{d} t$ is the slope of the curve during the first minute of ACMF exposure.

\section{The estimation of the amount of DOX released from $\mathrm{Fe}_{3} \mathrm{O}_{4} / \mathrm{DOX} / \mathrm{PPy}$-PEG-FA NPs by the application of ACMF}

The aqueous dispersion of $\mathrm{Fe}_{3} \mathrm{O}_{4} / \mathrm{DOX} /$ PPy-PEG-FA NPs $(0.25 \mathrm{mg} / \mathrm{mL})$ was placed in an ACMF with $H=8 \mathrm{kA} \mathrm{m}^{-1}$ and $f=230 \mathrm{kHz}(H f=$ $1.8 \times 10^{9} \mathrm{~A} \mathrm{~m}^{-1} \mathrm{~s}^{-1}$ ) for $1,5,10,15$, or $20 \mathrm{~min}$. The supernatant was collected by centrifugation $(20,000 \mathrm{~g}, 5$ h). The amount of DOX released from 
$\mathrm{Fe}_{3} \mathrm{O}_{4} /$ DOX/PPy-PEG-FA NPs was estimated by substituting the fluorescence intensity of the supernatant DOX in the calibration curve, which was prepared by measuring the fluorescence intensity of DOX aqueous solutions $(5,10,50$, and $100 \mu \mathrm{g} / \mathrm{mL})$.

\section{Ethics statement}

The study protocol was approved by the Animal Care and Use Committee of the University of Tokushima (Tokushima).

\section{Animals}

Female CB17/Icr-Prkdcscid mice aged 4 weeks were purchased from Charles River Laboratories (Yokohama) and maintained in a specific pathogen-free facility in our Animal Resources Center. To eradicate residual natural killer (NK) cells, mice were injected intraperitoneally with $10 \mu \mathrm{L}$ of rabbit anti-asialo GM1 antiserum (Wako Pure Chemicals, Osaka) 1 day before tumor inoculation. ${ }^{55}$ Inoculation with human multiple myeloma cells $\left(5 \times 10^{6}\right)$ was accomplished by subcutaneous injection into the back of the mice.

\section{In vivo therapeutic efficacy of the combination of MHT and chemotherapy}

The therapeutic efficacy of the combination of MHT and chemotherapy was investigated using mice with tumor volumes of $130 \mathrm{~mm}^{3}$. Tumor volumes were calculated by

$$
\mathrm{V}=\mathrm{AB}^{2} \Pi / 6,
$$

where $\mathrm{A}$ is the long and $\mathrm{B}$ is the short lateral diameter of the tumor. The mice were divided into 6 groups: no treatment $(n=8)$; intratumoral administration of 5 $\mathrm{mg} / \mathrm{kg}$ of $\mathrm{Fe}_{3} \mathrm{O}_{4} /$ DOX/PPy-PEG-FA NPs $(1 \mathrm{mg} / \mathrm{mL})$ $(n=6)$; application of $\mathrm{ACMF}(n=5)$; intratumoral administration of $0.13 \mathrm{mg} / \mathrm{kg}$ of DOX, which is equivalent to the amount of DOX released from 5 $\mathrm{mg} / \mathrm{kg}$ of $\mathrm{Fe}_{3} \mathrm{O}_{4} /$ DOX/PPy-PEG-FA NPs $(1 \mathrm{mg} / \mathrm{mL})$ $(n=8)$; application of ACMF $24 \mathrm{~h}$ after intravenous administration of $5 \mathrm{mg} / \mathrm{kg}$ of $\mathrm{Fe}_{3} \mathrm{O}_{4} /$ PPy-PEG-FA $\operatorname{NPs}(1 \mathrm{mg} / \mathrm{mL})(n=5)$; and application of ACMF $24 \mathrm{~h}$ after intravenous administration of $5 \mathrm{mg} / \mathrm{kg}$ of $\mathrm{Fe}_{3} \mathrm{O}_{4} /$ PPy-PEG-FA NPs $(n=5)$. The $H, f$, and application time of ACMF were $8 \mathrm{kA} \mathrm{m}^{-1}, 230 \mathrm{kHz}$, and 20 min, respectively. $\mathrm{Fe}_{3} \mathrm{O}_{4} / \mathrm{DOX} / \mathrm{PPy}-\mathrm{PEG}-\mathrm{FA} \mathrm{NPs}$, $\mathrm{Fe}_{3} \mathrm{O}_{4} /$ PPy-PEG-FA NPs, and DOX were injected in one shot. The mice were killed when the tumor volume reached $15,000 \mathrm{~mm}^{3}$.

\section{Histological analyses}

The tissue samples obtained for histology were immediately immersed in a $4 \%$ paraformaldehyde solution for $24 \mathrm{~h}$. Fixed tissues were encased in paraffin blocks. Tissue sections $(2 \mu \mathrm{m})$ were cut from the paraffin blocks and affixed to Superfrost Microscopy Slides. Hematoxylin and eosin staining of tissue sections was carried out in a conventional manner.

\section{Toxicity evaluation}

$\mathrm{Fe}_{3} \mathrm{O}_{4} /$ DOX/PPy-PEG-FA NPs (5 mg/kg) were injected intravenously into mice ( $n=5$ per cohort). Blood samples were collected $24 \mathrm{~h}$ after injection, and serum was obtained by centrifugation of whole blood at 3,000 rpm for $15 \mathrm{~min}$. The biochemical parameters (TP, ALB, AST, ALT, BUN, Na, Cl, T-BIL, and T-CHO) in the serum were determined using an automated biochemical analyzer (Hitachi 7180, Tokyo). Furthermore, $24 \mathrm{~h}$ after injection, the heart, liver, lung, kidney, and spleen were enucleated, and their weights were measured using an electric balance.

\section{Supplementary Material}

Fig.S1 - Fig.S12.

http://www.thno.org/v04p0834s1.pdf

\section{Acknowledgements}

This work was supported by Grant-in-Aid for Young Scientists (A) (26709050) and Young Scientists (B) (24760551) from the Japan Society for the Promotion of Science (JSPS). This work was also supported by Adaptable and Seamless Technology Transfer Program (A-STEP) through target-driven R\&D (Exploratory Research) (AZ251Z00996M), JST.

\section{Competing Interests}

The authors have declared that no competing interest exists.

\section{References}

1. Mornet S, Vasseur S, Grasset F, Duguet E. Magnetic nanoparticle design for medical diagnosis and therapy. J Mater Chem. 2004; 14: 2161-75.

2. Cole AJ, Yang VC, David AE. Cancer theranostics: the rise of targeted magnetic nanoparticles. Trends Biotechnol. 2011; 29:323-32.

3. Yen SK, Padmanabhan P, Selvan ST. Multifunctional iron oxide nanoparticles for diagnostics, therapy and macromolecule delivery. Theranostics. 2013; 3: 986-1003.

4. Reddy LH, Arias JL, Nicolas J, Couvreur P. Magnetic nanoparticles: design and characterization, toxicity and biocompatibility, pharmaceutical and biomedical applications. Chem Rev. 2012; 112: 5818-78.

5. Colombo M, Carregal-Romero S, Casula MF, Gutiérrez L, Morales MP, Böhm IB, Heverhagen JT, Prosperi D, Parak WJ. Biological applications of magnetic nanoparticles. Chem Soc Rev. 2012; 41: 4306-34.

6. Saldívar-Ramírez MMG, Sánchez-Torres CG, Cortés-Hernández DA, Escobedo-Bocardo JC, Almanza-Robles JM, Larson A, Reséndiz-Hernández PJ, Acuña-Gutiérrez IO. Study on the efficiency of nanosized magnetite and mixed ferrites in magnetic hyperthermia. J Mater Sci: Mater Med. 2014; DOI 10.1007/s10856-014-5187-3.

7. Jordan A, Scholz R, Wust P, Fähling H, Felix R. Magnetic fuid hyperthermia (MFH): Cancer treatment with AC magnetic field induced excitation of biocompatible superparamagnetic nanoparticles. J Magn Magn Mater. 1999; 201: 413-9.

8. Guardia P, Corato RD, Lartigue L, Wilhelm C, Espinosa A, Garcia-Hernandez M, Gazeau F, Manna L, Pellegrino T. Water-soluble iron oxide nanocubes with high values of specific absorption rate for cancer cell hyperthermia treatment. ACS Nano. 2012; 6: 3080-91.

9. Klostergaard J, Seeney CE. Magnetic nanovectors for drug delivery. Nanomed Nanotechnol Biol Med. 2012; 8: S37-50.

10. Lartigue L, Hugounenq P, Alloyeau D, Clarke SP, Lévy M, Bacri JC, Bazzi R, Brougham DF, Wilhelm C, Gazeau F. Cooperative organization in iron oxide 
multi-core nanoparticles potentiates their efficiency as heating mediators and MRI contrast agents. ACS Nano. 2012; 6: 10935-49.

11. Qiu P, Jensen C, Charity N, Towner R, Mao C. Oil phase evaporation-induced self-assembly of hydrophobic nanoparticles into spherical clusters with controlled surface chemistry in an oil-in-water dispersion and comparison of behaviors of individual and clustered iron oxide nanoparticles. J Am Chem Soc. 2010; 132: 17724-32.

12. Hayashi $K$, Nakamura M, Sakamoto W, Yogo T, Miki H, Ozaki S, Abe M, Matsumoto T, Ishimura K. Superparamagnetic nanoparticle clusters for cancer theranostics combining magnetic resonance imaging and hyperthermia treatment. Theranostics. 2013; 3: 366-76.

13. Alphandéry E, Faure S, Seksek O, Guyot F, Chebbi I. Chains of magnetosomes extracted from AMB-1 magnetotactic bacteria for application in alternative magnetic field cancer therapy. ACS Nano. 2011; 5: 6279-96.

14. Zhao Q, Wang L, Cheng R, Mao L, Arnold RD, Howerth EW, Chen ZG, Platt S. Magnetic nanoparticle-based hyperthermia for head \& neck cancer in mouse models. Theranostics. 2012; 2: 113-21.

15. Bae KH, Park M, Do MJ, Lee N, Ryu JH, Kim GW, Kim CG, Park TG, Hyeon T. Chitosan Oligosaccharide-stabilized ferrimagnetic iron oxide nanocubes for magnetically modulated. ACS Nano. 2012; 6: 5266-73.

16. Arias JL, Reddy $\mathrm{LH}$, Couvreur $\mathrm{P}$. $\mathrm{Fe}_{3} \mathrm{O}_{4}$ /chitosan nanocomposite for magnetic drug targeting to cancer. J Mater Chem. 2012; 22: 7622-32.

17. Brown JM, Giaccia AJ. The unique physiology of solid tumors: opportunities (and problems) for cancer therapy. Cancer Res. 1998; 58: 1408-16.

18. Mura S, Nicolas J, Couvreur P. Stimuli-responsive nanocarriers for drug delivery. Nat Mater. 2013; 12: 991-1003.

19. Needham D, Anyarambhatla G, Kong G, Dewhirst MW. A new temperature-sensitive liposome for use with mild hyperthermia: characterization and testing in a human tumor xenograft model. Cancer Res. 2000; 60: 1197-1201.

20. Kong G, Anyarambhatla G, Petros WP, Braun RD, Colvin OM, Needham D, Dewhirst MW. Efficacy of liposomes and hyperthermia in a human tumor xenograft model: importance of triggered drug release. Cancer Res. 2000; 60: 6950-7.

21. Meyer DE, Shin BC, Kong GA, Dewhirst MW, Chilkoti A. Drug targeting using thermally responsive polymers and local hyperthermia. J Control Release. 2001; 74: 213-24.

22. Chilkotia A, Drehera MR, Meyera DE, Raucher D. Targeted drug delivery by thermally responsive polymers. Adv Drug Deliv Rev. 2002; 54: 613-30.

23. Leal MP, Torti A, Riedinger A, Fleur RL, Petti D, Cingolani R, Bertacco R, Pellegrino T. Controlled release of doxorubicin loaded within magnetic thermoresponsive nanocarriers under magnetic and thermal actuation in a microfluidic channel. ACS Nano. 2012; 6: 10535-45.

24. Deka SR, Quarta A, Corato RD, Riedinger A, Cingolani R, Pellegrino T. Magnetic nanobeads decorated by thermo-responsive PNIPAM shell as medical platforms for the efficient delivery of doxorubicin to tumour cells. Nanoscale 2011; 3: 619-29.

25. Riedinger A, Guardia P, Curcio A, Garcia MA, Cingolani R, Manna L, Pellegrino T. Subnanometer local temperature probing and remotely controlled drug release based on azo-functionalized iron oxide nanoparticles. Nano Lett. 2013; 13: 2399-406

26. Bonini M, Berti D, Baglioni P. Nanostructures for magnetically triggered release of drugs and biomolecules. Curr Opin Colloid Interface Sci. 2013; 18: $459-67$.

27. Gautier J, Allard-Vannier E, Munnier E, Soucé M, Chourpa I. Recent advances in theranostic nanocarriers of doxorubicin based on iron oxide and gold nanoparticles. J Control Release. 2013; 169: 48-61.

28. Chandra S, Barick KC, Bahadur D. Oxide and hybrid nanostructures for therapeutic applications. Adv Drug Deliv Rev. 2011; 63: 1267-81.

29. Pradhan P, Giri J, Rieken F, Koch C, Mykhaylyk O, Döblinger M, Banerjee R, Bahadur D. Plank C. Targeted temperature sensitive magnetic liposomes for thermo-chemotherapy. J Control Release. 2010; 142: 108-21.

30. Timko BP, Kohane DS. Materials to clinical devices: technologies for remotely triggered drug delivery. Clin Ther. 2012; 34: S25-35.

31. Timko BP, Dvir T, Kohane DS. Remotely triggerable drug delivery systems. Adv Mater. 2010; 22: 4925-43.

32. Hoare T, Timko BP, Santamaria J, Goya GF, Irusta S, Lau S, Stefanescu CF, Lin D, Langer R, Kohane DS. Magnetically triggered nanocomposite membranes: a versatile platform for triggered drug release. Nano Lett. 2011; 11: 1395-400.

33. Hoare T, Santamaria J, Goya GF, Irusta S, Lin D, Lau S, Padera R, Langer R, Kohane DS. A Magnetically Triggered Composite Membrane for On-Demand Drug Delivery. Nano Lett. 2009; 9: 3651-7.

34. Ruiz-Hernández R, Baeza A, Vallet-Regí M. Smart drug delivery through DNA/magnetic nanoparticle gates. ACS Nano. 2011; 5: 1259-66.

35. Baeza A, Guisasola E, Ruiz-Hernández E, Vallet-Regí M, Chem M. Magnetically triggered multidrug release by hybrid mesoporous silica nanoparticles. Chem Mater 2012; 24: 517-24.

36. Knežević NZ, Ruiz-Hernández E, Hennink WE, Vallet-Regí M. Magnetic mesoporous silica-based core/shell nanoparticles for biomedical applications. RSC Adv. 2013; 3: 9584-93.

37. Huang HY, Hu SH, Chian CS, Chen SY, Laia HY, Chen YY. Self-assembling PVA-F127 thermosensitive nanocarriers with highly sensitive magnetically-triggered drug release for epilepsy therapy in vivo. J Mater Chem. 2012; 22: 8566-73.

38. Renard PE, Jordan O, Faes A, Petri-Fink A, Hofmann H, Rüfenacht D, Bosman $\mathrm{F}$, Buchegger F, Doelker $\mathrm{E}$. The in vivo performance of magnetic parti- cle-loaded injectable, in situ gelling, carriers for the delivery of local hyperthermia. Biomaterials. 2010; 31: 691-705.

39. Chen Y, Bose A, Bothun GD. Controlled release from bilayer-decorated magnetoliposomes via electromagnetic heating. ACS Nano 2010; 4: 3215-21.

40. Bothun GD, Preiss MR. Bilayer heating in magnetite nanoparticle-liposome dispersions via fluorescence anisotropy. J Colloid Interface Sci. 2011; 357: 70-4.

41. Bothun GD, Lelis A, Chen Y, Scully K, Anderson LE, Stoner MA. Multicomponent folate-targeted magnetoliposomes: design, characterization, and cellular uptake. Nanomed -Nanotechnol Biol Med. 2011; 7: 797-805.

42. Hayashi K, Ono K, Suzuki H, Sawada M, Moriya M, Sakamoto W, Yogo T. High-frequency, magnetic-field-responsive drug release from magnetic nanoparticle/organic hybrid based on hyperthermic effect. ACS Appl Mater Interfaces 2010; 2: 1903-11.

43. Hayashi K, Shimizu T, Asano H, Sakamoto W, Yogo T. Synthesis of spinel iron oxide nanoparticle/organic hybrid for hyperthermia. J Mater Res. 2008; 23: 3415-24.

44. Hayashi K, Moriya M, Sakamoto W, Yogo T. Chemoselective synthesis of folic acid-functionalized magnetite nanoparticles via click chemistry for magnetic hyperthermia. Chem Mater. 2009; 21: 1318-25.

45. Hayashi K, Ono K, Suzuki H, Sawada M, Moriya M, Sakamoto W, Yogo T. One-pot biofunctionalization of magnetic nanoparticles via thiol-ene click reaction for magnetic hyperthermia and magnetic resonance imaging. Chem Mater. 2010; 22: 3768-72.

46. Yu MK, Park J, Jon S. Targeting strategies for multifunctional nanoparticles in cancer imaging and therapy. Theranostics. 2012; 2: 3-44.

47. Hayashi K, Nakamura M, Miki H, Ozaki S, Abe M, Matsumoto T, Kori T, Ishimura K. Photostable iodinated silica/porphyrin hybrid nanoparticles with heavy-atom effect for wide-field photodynamic/photothermal therapy using single light source. Adv Funct Mater. 2014; 24: 503-13.

48. Hayashi K, Nakamura M, Miki H, Ozaki S, Abe M, Matsumoto T, Ishimura K. Near-infrared fluorescent silica/porphyrin hybrid nanorings for in vivo cancer imaging. Adv Funct Mater. 2012; 22: 3539-46.

49. Hayashi K, Nakamura M, Miki H, Ozaki S, Abe M, Matsumoto T, Ishimura K. Gold nanoparticle cluster-plasmon-enhanced fluorescent silica core-shell nanoparticles for x-ray computed tomography-fluorescence dual-mode imaging of tumors. Chem Commun. 2013; 49: 5334-6.

50. Silverstein RM, Webster FX, Kiemle DJ. Spectrometric Identification of Organic Compounds, 7th Ed. New York, USA: John Wiley \& Sons; 2005.

51. Wu W, Xiao XH, Ren F, Zhang SF, Jiang CZ. A comparative study of the magnetic behavior of single and tubular clustered magnetite nanoparticles. J Low Temp Phys. 2012; 168: 306-13.

52. Sano K, Nakajima T, Choyke PL, Kobayashi H. Markedly Enhanced Permeability and Retention Effects Induced by Photo-immunotherapy of Tumors. ACS Nano. 2013; 7: 717-24

53. Hong JY, Yoon H, Jang J. Kinetic study of the formation of polypyrrole nanoparticles in water-soluble polymer/metal cation systems: a light-scattering analysis. Small. 2010; 6: 679-86.

54. Hayashi K, Ono K, Suzuki H, Sawada M, Moriya M, Sakamoto W, Yogo T. Electrosprayed synthesis of red-blood-cell-like particles with dual modality for magnetic resonance and fluorescence imaging. Small. 2010; 6: 2384-91.

55. Ozaki S, Kosaka M, Wakatsuki S, Abe M, Koishihara Y, Matsumoto T. Immunotherapy of multiple myeloma with a monoclonal antibody directed against a plasma cell-specific antigen, HM1.24. Blood. 1997; 90: 3179-86. 